\title{
Unveiling the hinterland: a new type of Hellenistic rural settlement in Crimea
}

\author{
Vladimir F. Stolba \& Jens Andresen*
}

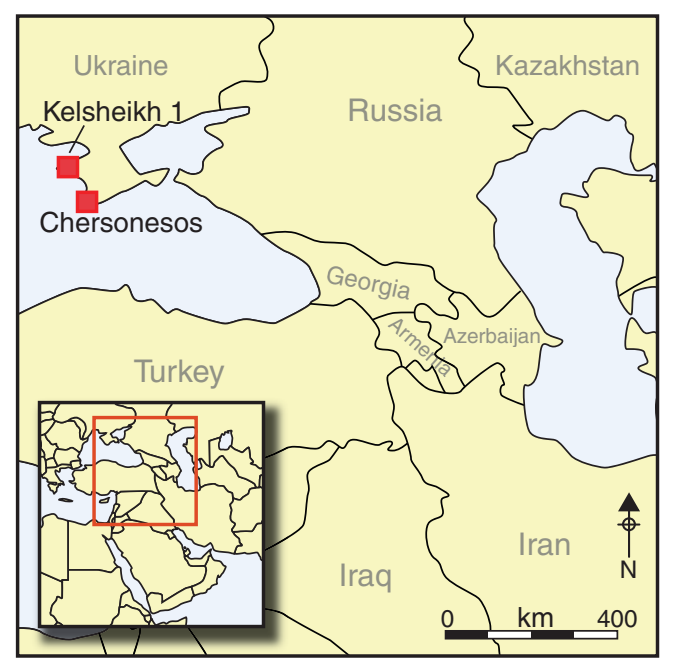

Except for some excavated coastal sites, the rural hinterland of ancient Chersonesos on the Tarkhankut Peninsula in north-west Crimea has been understood only from pot scatters recorded during landscape survey and fieldwalking. The city's rural territory (chora) thrived from the fourth to second century BC, but little is known of the identity of its inhabitants, especially those in the inland areas. This paper presents the results of the first systematic excavations in this part of the peninsula. The results challenge previous notions that the territory was occupied by nomadic indigenous communities and reveal that the site shared the fate of the entire Chersonesean chora, meeting a violent end in the early part of the third century $B C$.

Keywords: Crimea, Chersonesos, Hellenistic, rural economy, chora, landscape survey, cultural encounters

\section{Introduction}

Large amounts of quantifiable archaeological data from recent surveys in the Mediterranean and beyond have significantly advanced our understanding of settlement in the ancient countryside. However, problems associated with the interpretation of surface assemblages (Bintliff \& Snodgrass 1988; Pettegrew 2001; Foxhall 2004), and limited excavation of Classical and Hellenistic rural sites (Jones et al. 1962, 1973; Keller \& Walles 1988; Lohmann 1993a \& b; Pentinnen 2001; Adam-Veleni et al. 2003; Galaty et al. 2004; KaramitrouMentesidi 2009), leave many questions unresolved. These include: the proportion of the population settled in the hinterland (Finley 1987-1989; Cartledge 1998; Hansen 2006); the structure and productivity of the rural economy; the organisation, social and ethnocultural composition of labour, and the identity and character of the Classical farmstead-a

* Department of Culture and Society, Aarhus University, Jens Chr. Skous Vej 3, DK-8000 Aarhus C, Denmark (Author for correspondence: Vladimir Stolba; Email: klavs@cas.au.dk) 
significant feature of the rural landscape in antiquity (Osborne 1992; Pettegrew 2001; Cherry 2003).

Although most of the collected data still await publication rural landscapes in the colonial settings of southern Italy (Adamesteanu 1974; Carter 2006a; Lanza Catti et al. 2014) and the northern Pontic area (Kryžickij et al. 1989), particularly in Crimea, are notable because numerous sites have been excavated systematically since the 1950s (Strželeckij 1961; Ščeglov 1978, 1987; Kolesnikov 1984; Kovalenko 1991; Stolba 1991; Chtcheglov 1992; Saprykin 1994, 2003; Maslennikov 1998; Daševskaja \& Golencov 1999; Hannestad et al. 2002; Solov'ev 2003; Zin'ko 2003; Popova \& Kovalenko 2005).

This paper presents the results of the 2010-2011 excavations conducted by the Danish-Russian-Ukrainian Western Crimean Archaeological Project (WCAP) in the Chernomorskoye district of Crimea, which shed new light on some of the vexed questions mentioned above. They are the first systematic excavations in the distant hinterland of the Greek city of Chersonesos, whose rural territory was previously understood exclusively on the basis of surface material from surveys and excavation of selected sites on the coast.

Western Crimea was the agricultural territory (chora) of Tauric Chersonesos from the fourth to second centuries BC, and boasts some of the best-preserved Classical rural landscapes anywhere. Traces of land division are still clearly visible on the Herakleian Peninsula in the vicinity of modern-day Sevastopol; this has generated scholarly interest in the area, particularly in the years following the Russian Empire's annexation of Crimea (Tunkina 2003; Zubar' 2007). The scientific importance of the area and its significance in defining current cultural identity have been acknowledged by the inscription of the city of Chersonesos and its rural territory on UNESCO's World Heritage List.

Founded at the Quarantine Bay in the late sixth or early fifth century BC (Vinogradov \& Zolotarev 1990, 1999; Stojanov 2007; cf. Bujskich 2006), the city was designed on a Hippodamian grid plan (Carter et al. 2000; Carter 2006b; Nikolaenko 2006). Dating to the second half of the fourth century BC and delineated by roads and stone walls, the Greek land division system around Chersonesos, like the city itself, followed an orthogonal grid pattern with equal spacing of one stadion (approximately $210 \mathrm{~m}$ ) along its axis. Labourers were housed in large farms that were distributed throughout the chora and that respected the grid plan.

A colony of Herakleia Pontike, Chersonesos, which Pliny (Natural History 4.33; Mayhoff 1906) called the most polished city throughout the region due to its strict preservation of Greek customs, is the only Doric foundation on the northern shore of the Black Sea. Its agricultural territory spread in a continuous stretch along the western coast of Crimea for over $200 \mathrm{~km}$ to the peninsula of Tarkhankut, where the city's distant chora was situated (Figure 1). Late Classical and Hellenistic settlements have been investigated in this area, one of the largest and best studied of which is the settlement of Panskoye I (Hannestad et al. 2002; Stolba 2012; Stolba \& Rogov 2012). Aerial photographs suggest that, like the immediate chora in the vicinity of Chersonesos, the distant chora was also divided into a system of orthogonal land plots (Ščeglov 1978, 1980; Chtcheglov 1992: 250-58). Yet, with the exception of a few areas on the coast near Cape Oirat and at Vetrenaya Bay, $1.5 \mathrm{~km}$ north of the district centre of Chernomorskoye, no physical remains of divisions have been verified on the ground so far (see Lisetskii et al. 2013). Unlike the city's immediate chora (C) Antiquity Publications Ltd, 2015 

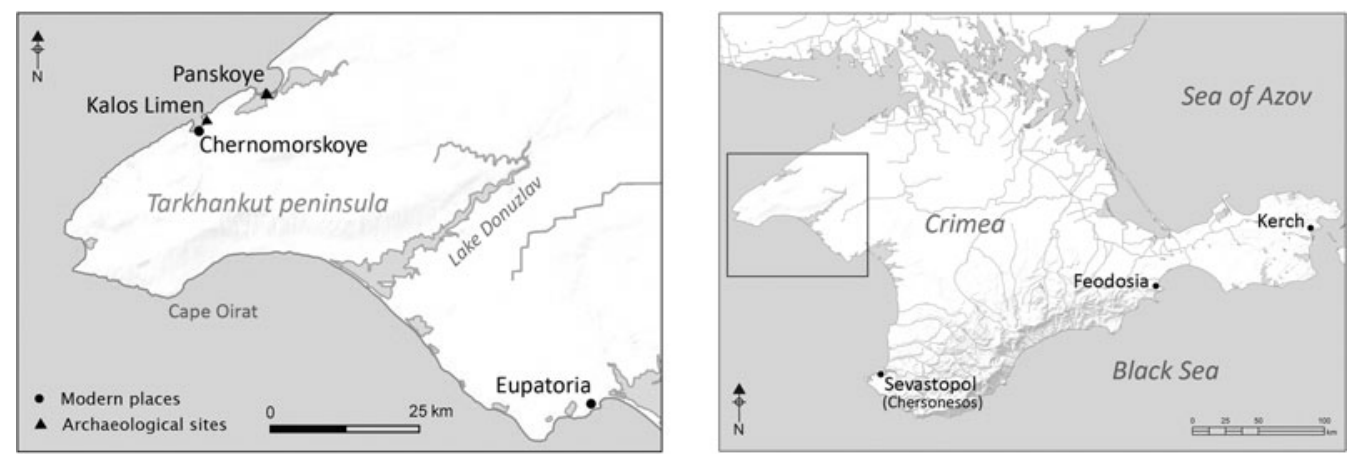

Figure 1. Map of Crimea showing locations mentioned in the text.

in south-western Crimea, no contemporary farmhouses have yet been identified inside the proposed area of land division in the inland region of the Tarkhankut Peninsula. Until very recently, inland hill-slopes were viewed as the territory of nomads, who left no settlement traces, only burial mounds.

Some of these issues were addressed by the Dzharylgach Survey Project in 2007-2008; Panskoye's hinterland was surveyed using systematic fieldwalking of ploughed areas and unploughed hill-slopes. As expected, the ploughed zone revealed clusters of surface finds, some of which were interpreted as marking the location of sites. Although no excavations were conducted, it is evident that these clusters of surface finds differ in scale from both the area's coastal sites and the farms near to Chersonesos. More intriguing discoveries were made on the largely un-ploughed slopes of Tarkhankut, where the remains of numerous wellpreserved stone structures have been identified. Surface finds of Greek pottery suggested that these sites were connected with rural Greek settlements on the coast. However, the nature of this connection remained unclear. Most importantly, these findings challenged the theory that the inland was inhabited by a non-sedentary indigenous population (Guldager Bilde et al. 2007, 2012). The Western Crimean Archaeological Project discovered over 200 new sites, confirming discoveries made by the Dzharylgach Survey Project throughout the Tarkhankut Peninsula (Smekalova \& Stolba 2009; Stolba 2012: 312). Although the project did not systematically investigate areas east of Lake Donuzlav, examination of satellite imagery clearly indicates that the pattern continues beyond this natural boundary.

\section{Excavation results}

An example of the newly discovered inland settlements is stone structure $\mathrm{H} 1$ at Kelsheikh 1, which was fully excavated in 2010 and 2011 (see Stolba et al. 2011). The investigation revealed an ancient farmhouse of a type hitherto unknown in the territory of Chersonesos. The building plan and materials of the structure, as well as the pottery assemblage it contained, deviate from those typical of rural sites in the coastal zone and the farmhouses near Chersonesos. The closest parallels are located on the Kerch Peninsula, several hundred kilometres away (Maslennikov 1998). These results are of the utmost importance to the study 


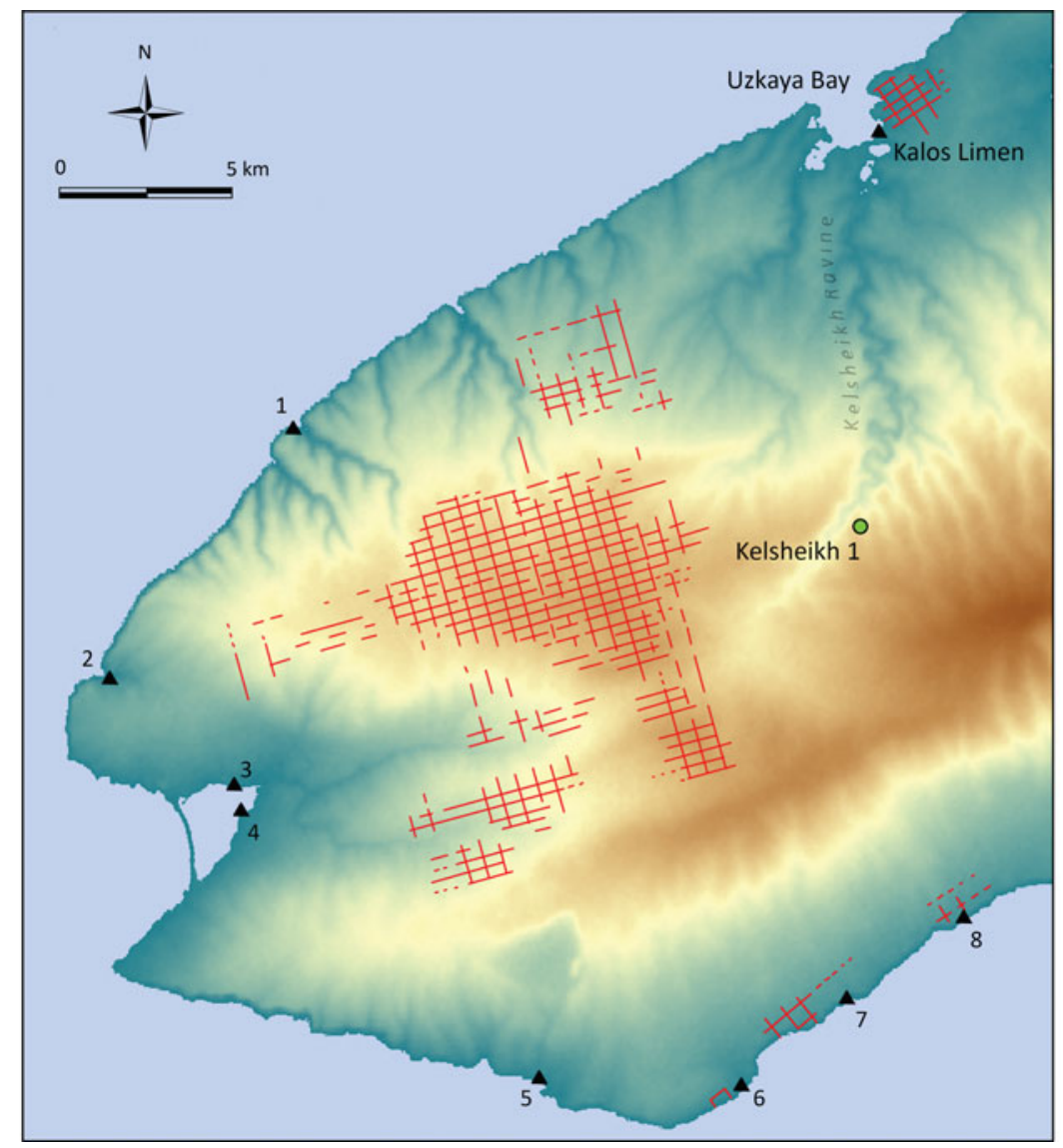

Figure 2. Digital elevation model showing the location and extent of the gridded fields identified by Šceglov (1980), and the position of Kelsheikh 1 and principal Greek coastal sites: 1) Bolshoy Kastel; 2) Ocheretay; 3) Karadzha; 4) Karadzha 3 (S12-038); 5) Melovoe; 6) Oirat; 7) Dzhan-Baba; 8) Ak-Saray.

of the ancient Greek countryside, especially for understanding the complex relationship between Greek states and indigenous peoples.

Identified in 2009 and named after an abandoned village just $600 \mathrm{~m}$ north of its location, the settlement of Kelsheikh 1 is situated about $7 \mathrm{~km}$ south of the district capital of Chernomorskoye, which lies at the mouth of the peninsula's largest ravine, emptying into Uzkaya Bay (Figure 2). Cutting through limestone bedrock, the ravine meanders from the watershed on the plateau in the south-west towards the coast. Steep slopes make it difficult to cross, so it forms a natural east-west communication barrier. In the bottom of the ravine is a sheltered pathway and it is the most convenient place to dig wells in a semi-arid landscape without other freshwater resources.

Kelsheikh 1 occupies the gentle western slope of a side branch of the main ravine and has intervisibility with the modern village and the ancient fortified settlement of Chernomorskoye, traditionally associated with Kalos Limen of the written sources (Arrian, Periplus Ponti Euxini 30-31; Silberman 1995; Ptolemy, Geographia 3.5.1; Müller 1883;

(C) Antiquity Publications Ltd, 2015 


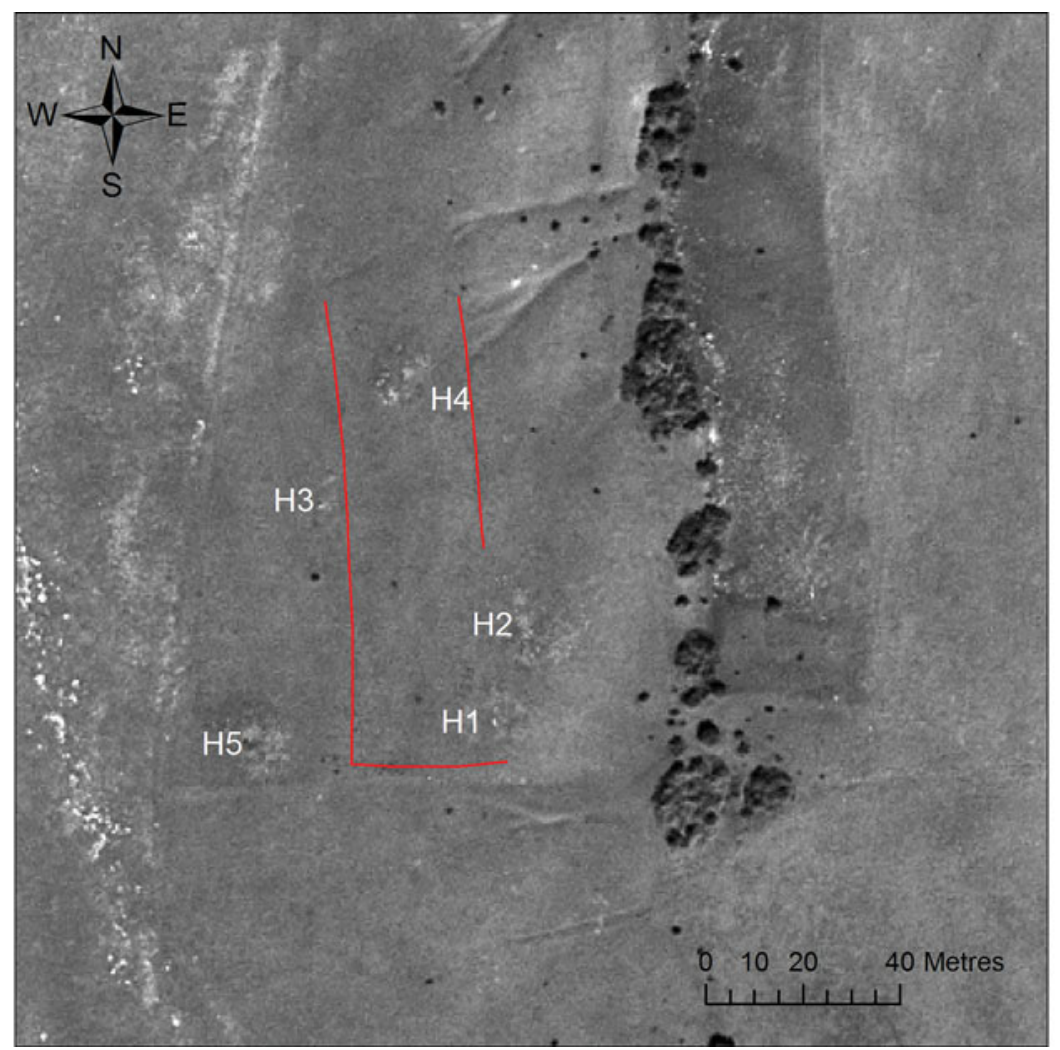

Figure 3. Satellite image of Kelsheikh I with identification of structures (houses: H1-H5; embankments: red lines). Image courtesy of the GeoEye Foundation.

IOSPE I ( $2^{\text {nd }}$ ed.) 401, 352, 353; Latyshev 1916; Talbert 2000: map 23 G2-3; Stolba 2004: 56 , note 38$)$. It covers an area of 0.8 ha and encloses five similarly orientated structures (houses $\mathrm{H} 1-\mathrm{H} 5$ ), discernible in the terrain as elevations with suppressed vegetation and stone debris. A low earthen embankment running from east to west delimits the settlement area to the south, and two other low earthen banks run parallel to the ravine from north to south and respect the stone structures (Figure 3). The soil chronology (see Lisetskii et al. 2013; Stolba et al. 2013) suggests they are roughly contemporary with the stone structures. In addition, geomagnetic surveys revealed two waste dumps east of $\mathrm{H} 1$ and $\mathrm{H} 4$, as well as a number of small circular anomalies that proved to be storage pits; these were not visible on the ground, even after the removal of the topsoil. Apart from house $\mathrm{H} 5$, which grave robbers had apparently confused with a tumulus, the site appeared undisturbed. Excavation revealed a nicely dressed square stone_-presumably a field marker-found placed upright on top of a large piece of charred beech a few metres east of H5. Its position did not show any apparent relation to the earthen banks. The beech charcoal has a ${ }^{14} \mathrm{C}$ age of $149 \pm 23$ BP (1676-1941 AD at 68.2\% probability; AAR-15645; calibrated using OxCal v.4.2 and IntCal09 (Bronk Ramsey 2009; Reimer et al. 2009)). House 1 (which is the largest of the

(C) Antiquity Publications Ltd, 2015 


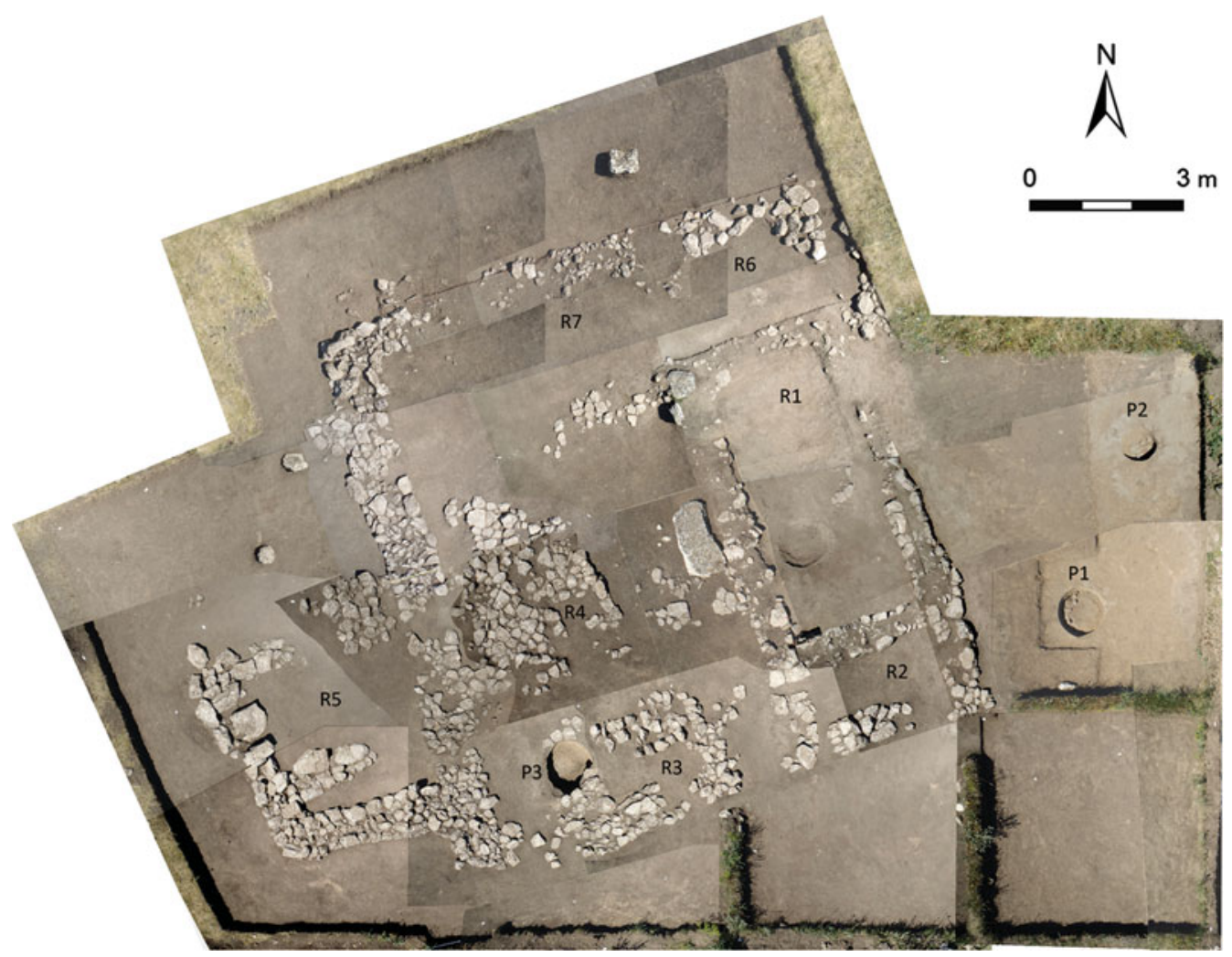

Figure 4. Photomosaic of house H1 at Kelsheikh I.

structures recorded at the site) was carefully excavated by hand. The fill of the associated storage pits was sampled for pollen and macro-fossils. Pollen and soil samples were also retrieved from above and below the stone debris, as well as from the geological section excavated just outside the house. All artefacts and ecofacts were collected and bagged for 100 per cent sampling, except for plentiful land snails (Helix albescens), which were partially sampled (Snegin et al. 2014). After detailed recording, the remains were preserved in situ by reinstating the topsoil.

\section{Structural remains}

Square in plan, with outer dimensions of $11.8 \times 11.8 \mathrm{~m}, \mathrm{H} 1$ contained six rooms (R1-4 and R6-7), arranged around a small, irregularly shaped courtyard. On its western side, an extra room (R5) was added to the main structure later, extending the total area to around $152 \mathrm{~m}^{2}$. The final plan of the structure, revealed by excavation, is the result of piecemeal alterations and repairs during its period of use (Figures $4 \& 5$ ).

The walls of the building are rarely preserved above one course of masonry placed directly on the ancient topsoil surface. However, the amount of stone debris suggests their original (C) Antiquity Publications Ltd, 2015 


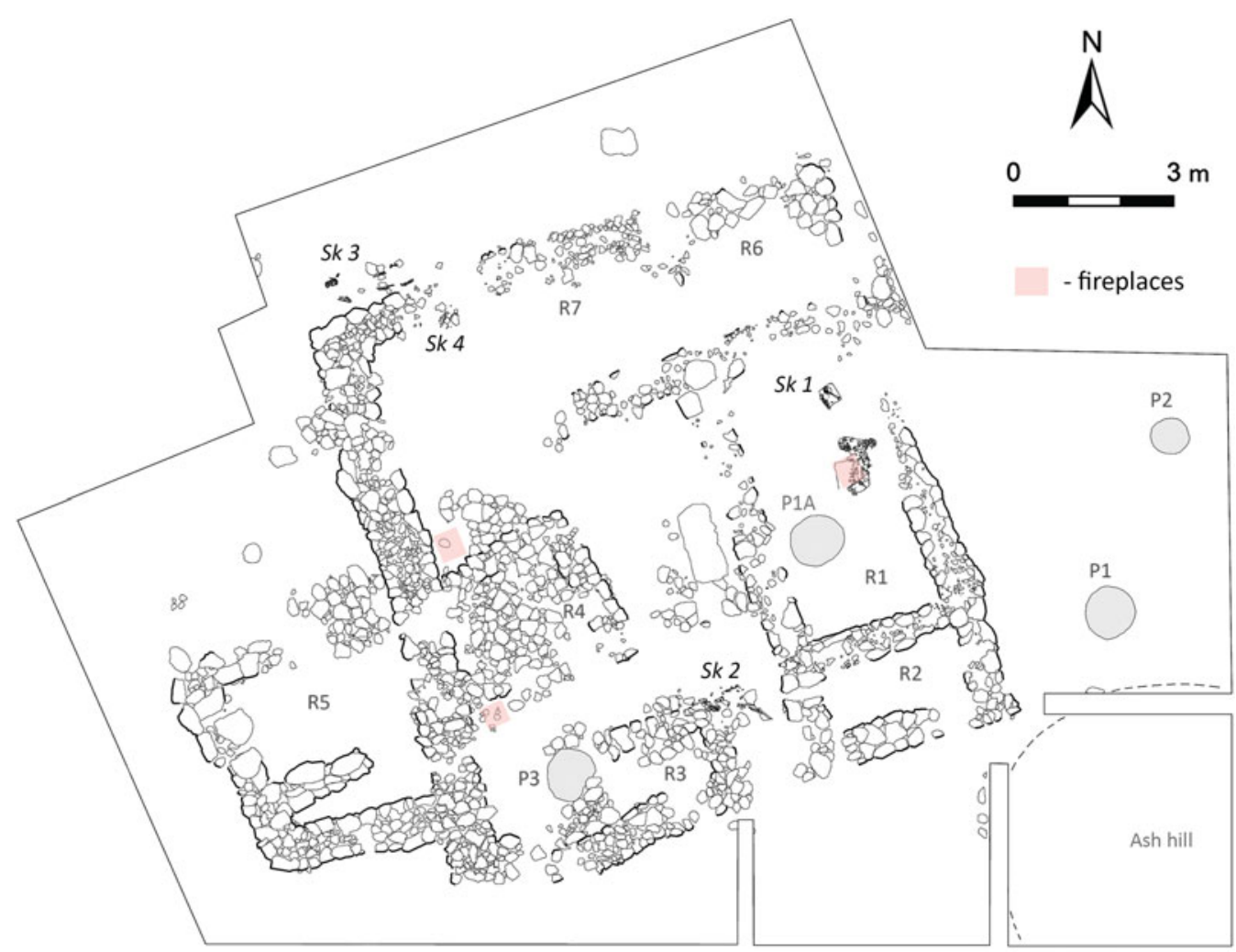

Figure 5. Plan of stone structure H1 with room (R) designations and indicating the location of fireplaces, pits $(P)$ and human remains (Sk).

height to be no less than three or four courses $(c .0 .5-0.6 \mathrm{~m})$ above ground. Wall construction varies in different sections, but generally the masonry is irregularly laid in two rows with smaller stones used for jointing. In some cases, large upright standing slabs were employed. The stones were either unworked or only very roughly chipped. In many cases, pottery fragments were inserted between irregular stones for better fitting and support. Average wall thicknesses matched those recorded at contemporary Greek coastal sites, with outer walls from 0.5 to $0.6 \mathrm{~m}$ thick, and inner walls about $50-100 \mathrm{~mm}$ thinner. The south-west wall of the house, at $1.05 \mathrm{~m}$ thick, was exceptional and was perhaps—as was the case with the embankments-designed to protect the structure from excessive rain-water run-off. Floors were earthen except for one room (R4) that was paved. The building material was limestone, collected or quarried locally. The significant amount of collapsed and in situ stone suggests many tons of stone were required for construction and that building a house was perhaps a collective endeavour involving a large workforce.

Questions regarding the type of superstructure (including roofing) cannot be answered definitively. Floors were roughly the same level as the ancient ground surface; if the roof level matched the height of the walls, even a short person could not have stood upright inside. One might consider a typical mud-brick superstructure on a stone foundation similar to the Greek farms of the coastal zone; however, there are no substantial mud-brick or wooden 
remains. Alternative types of roofing might have been a wooden construction with some sort of thatching, or even a woven woollen superstructure supported by poles, both of which are known from the ethnographic record (Feilberg 1944; Ethelberg 1966).

The courtyard $\left(c .37 \mathrm{~m}^{2}\right)$ was at the centre of the final building. The entrance leading to it was located in the south-western wall of the house, $1.25 \mathrm{~m}$ from its western corner. In front of the entrance, outside the building, was a stone pavement measuring $0.95 \times 0.80 \mathrm{~m}$. The doorway had a threshold made of large and middle-sized stones, and was $1.1 \mathrm{~m}$ wide. Except for R2, R6 and R5, all rooms could be entered directly from the courtyard.

The largest room $(\mathrm{R} 1)$ measured $5.20 \times 2.85 \mathrm{~m}\left(14.8 \mathrm{~m}^{2}\right)$ and must have served as a living unit. It formed the eastern side of the building together with R2, a small side room. The only regular internal fireplace was situated in R1, providing warmth and shelter in winter. It was $0.8 \mathrm{~m}$ wide, centrally located and fiercely scorched; it had a puddled-clay hearth and a kerb, constructed of stones, around one corner. A broken handmade pot was found in situ within the hearth deposits, along with a single fragment of amphora. Two other crushed handmade pots were found standing on the floor surface close to the fireplace. No charcoal was recovered, indicating that alternative fuel types, such as livestock dung, were used; dung was utilised in the area in later periods and is well attested ethnographically (Radde 2005: 392-93; Çelebi 2008: 47).

Room 4 was located opposite R1 on the south-west side of the building. It measured 2.35 $\times 1.75 \mathrm{~m}$, was self-contained and could be accessed via a doorway in the north-west wall that was $0.7 \mathrm{~m}$ wide. Outside this doorway was a small pavement, $1.0 \times 1.3 \mathrm{~m}$ in size. Room 4 also had a paved floor; rectangular holes in the paving in the eastern and northern corners of the room may suggest the presence of wooden structures. Aside from the handmade pots from R1, the only pottery recorded in the house that might have been intact or semi-intact at the time of destruction were two fragmentary, heavily re-used Chersonesean amphorae found in R4. Traces of outdoor fireplaces were documented from two locations adjacent to $\mathrm{R} 4$ and it is likely that this room was used as a kitchen.

Like R4, the tiny room R3, in the south side of the building, was also self-contained. In its north-east corner, a small table, measuring $1.0 \times 0.3 \mathrm{~m}$ and made from a single course of stones, was built against the wall. In the western part of the room, a cist-like stone structure that was sunk into the ground overlay an earlier storage pit. As was the case with the interconnecting R6 and R7 (located in the northern part of the building and with a shared single entrance from the courtyard), it is likely that R3 had some ancillary household function. However, the exact purpose remains unknown. The same is true for $\mathrm{R} 5$, an asymmetrical $2.8 \times 3.2 \mathrm{~m}$ annex that could be entered through a $0.8 \mathrm{~m}$-wide doorway in its south-western wall and contained a $2 \mathrm{~m}$-long stone pier that partitioned the room.

\section{Storage pits and rubbish dump}

A rubbish dump was located about $5 \mathrm{~m}$ east of $\mathrm{H} 1$. This ashy mound was not clearly defined in the terrain, but its light grey and very fine-grained soil differed markedly from the surroundings. Like the fireplaces, it contained no traces of charcoal. The dump included many artefacts (primarily pottery), some sherds of which fit together with fragments retrieved from the fill of nearby storage pit 1 .

(C) Antiquity Publications Ltd, 2015 
Pits 1 and 2, originally grain stores that later became dumps, are located 2-5m east of H1. Pit 1 was found $0.4 \mathrm{~m}$ below the modern ground surface; it was a circular pit with a diameter of $0.95 \mathrm{~m}$. Pear-shaped in section, it widened towards the flattened bottom to $1.3 \mathrm{~m}$ in diameter at a depth of approximately $1 \mathrm{~m}$. In two places, the walls of the pit were pierced by animal burrows. The smaller burrow was blocked with a stone, suggesting that the pit was repaired before finally falling out of use. The fill contained fragments of imported and handmade pottery, as well as animal bones and some fragmented and intensively scorched mud brick and stones. Flotation of the soil from the bottom of the pit recovered several cereal grains, among which barley (Hordeum vulgare) and rye (Secale sp.) were identified.

Pit 2 was discovered at about the same depth as Pit 1. It was bell-shaped, $1.75 \mathrm{~m}$ deep and $2.15 \mathrm{~m}$ wide at its bottom, and contained fragments of burned mud brick and household waste. Palaeobotanical finds included cereal grains from soft wheat (Triticum aestivum), barley and rye, as well as weed grasses. Numerous animal bones, largely deposited in the lowest fill, suggest rubbish may have been sorted prior to dumping, and also account for the virtual absence of faunal material on the surface of the site. The assemblage is dominated by sheep and goat. Cattle and horse are also documented, as is a single fragment of crab claw.

Two more pits were found inside structure H1 in R1 and R3. The pit in R1 had a depth of $0.4 \mathrm{~m}$ with an upper diameter of $1 \mathrm{~m}$; the pit in $\mathrm{R} 3$ was $0.84 \mathrm{~m}$ deep and had a diameter of $1.33 \mathrm{~m}$ at its bottom. Although the pits contained some household waste, no bones or palaeobotanical finds were recovered. Despite the absence of diagnostic finds, both pits stratigraphically pre-date the construction of the house.

\section{Human remains}

At several locations in and around the house, uninterred human skeletal remains were uncovered, suggesting that use of the site ended suddenly and dramatically, possibly as a result of a raid by nomads. In all but one case, the skeletons were disarticulated and incomplete, presumably due to animal scavenging. The collapse of the building made it difficult to distinguish between fractures caused by falling stone debris and those caused by violence. Nonetheless, despite generally poor bone preservation, lethal fractures were observed on Skeleton 1, found in R1 (Figure 6). The skeleton, which had a damaged parietal bone in the cranium, belonged to a sub-adult aged between 10 and 12 years. Two round, hollow stone amulets, similar to those used to ward off the evil eye (Stolba 2009), were found close to the skeleton.

Skeleton 2, found in the south-eastern part of the courtyard, was poorly preserved. However, traces of animal teeth-marks were visible on the humerus. The bones appear to have been those of a male, aged between 30 and 35 years. Fragments of a third skeleton found outside the building, close to its north-western wall, probably also belonged to an adult male. Individual pieces of tibiae, as well as one femur and one fibula, found in the courtyard suggest that a fourth person was present (Skeleton 4), but these bones could have been dragged to this location from elsewhere and belong to one of the other skeletons. 


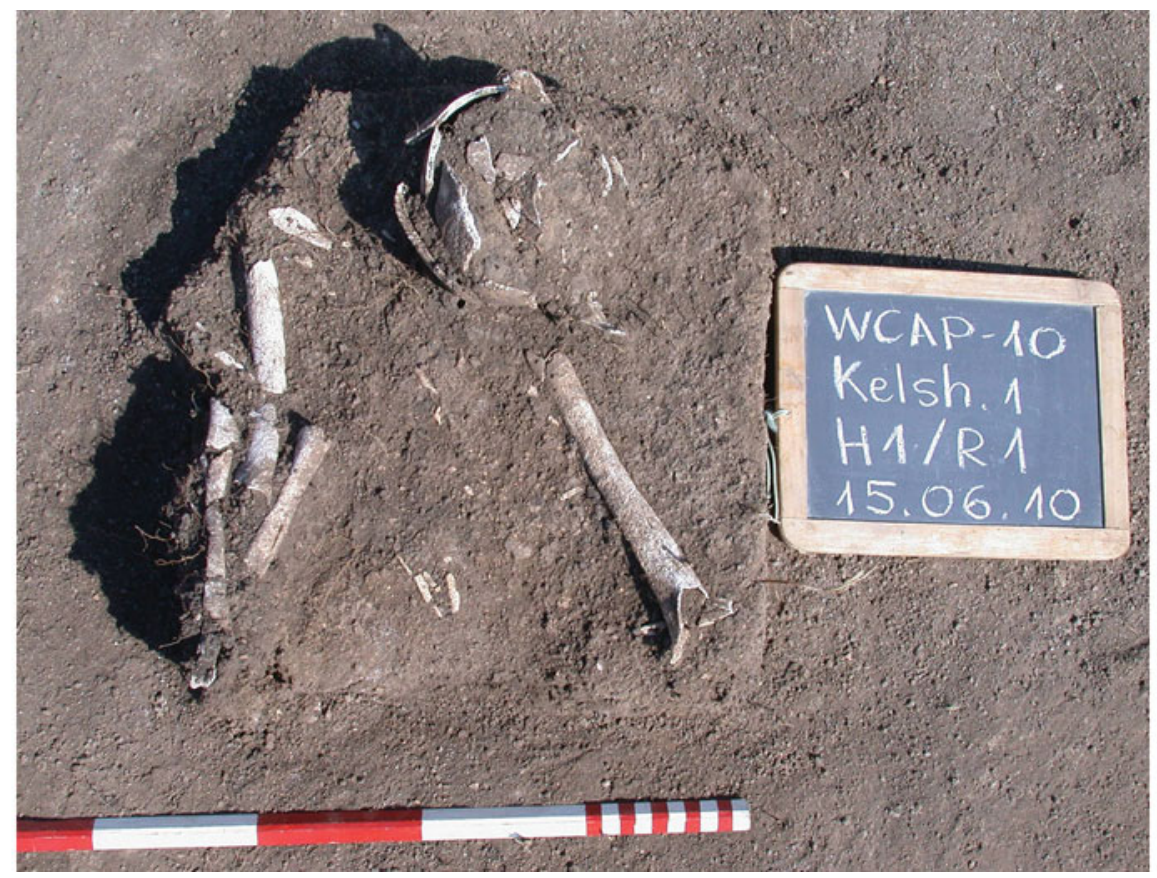

Figure 6. Skeleton 1 from house H1 at Kelsheikh I. Photograph by V.F. Stolba.

\section{The finds assemblage}

Compared with the abundance of ceramic material found at Greek habitations along the coast, the finds from $\mathrm{H} 1$ are very poor and reflect a modest daily life (Figure 7). The meagre amount of imported pottery is striking. Except for single fragments of black-glazed Attic ware, the assemblage mainly represents Chersonesean workshop productions. Imported plain and fine ware survives only in small sherds, and was found in the storage pits; it is clear that this pottery was not in use in the final days of occupation. Two fragmentary Chersonesean amphorae found in R4 show traces of wear and repair. Larger fragments of wine jars were mainly used as building material in the walls. The assemblage is dominated by handmade ware representing local Scythian and Kizil-Koba (Taurian) types (Figure 7, nos. 9-11). As one would expect, refuse areas (Pits 1 and 2 and the ash heap) contained higher concentrations of finds than the living floor (except the living room R1).

The scarcity of metal is another distinctive feature of the finds assemblage. A single lead spindle whorl found in R1, a few fragments of iron knives from a pit and a single bronze arrowhead of the so-called Scythian type found in the dumping area were the only metal objects recovered. Despite the absence of other metal tools and farming implements, the presence of grinding stones re-used as building material, storage pits and charred grains, suggest that the production and processing of cereals was a key part of the farm's economic activity.

It could be argued that the site appears impoverished because of subsequent scavenging or looting. However, this does not explain the paucity of imported wares at $\mathrm{H} 1$ in contrast

(C) Antiquity Publications Ltd, 2015 


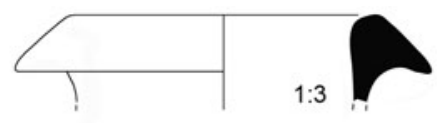

1
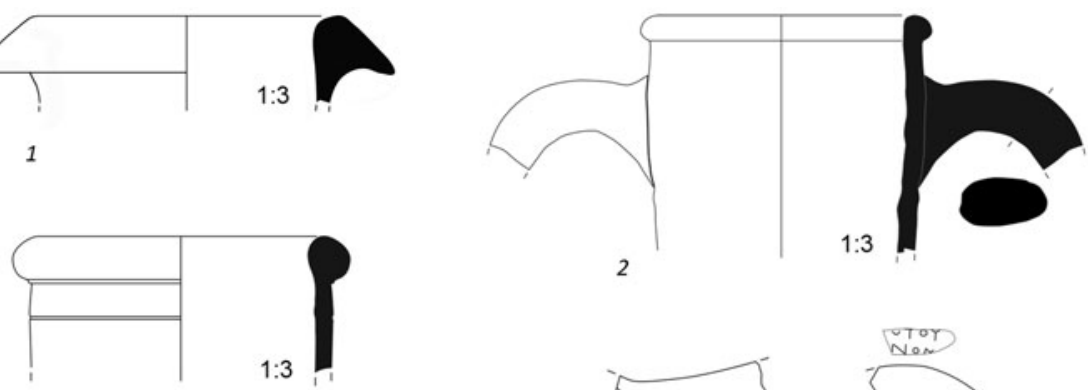

3

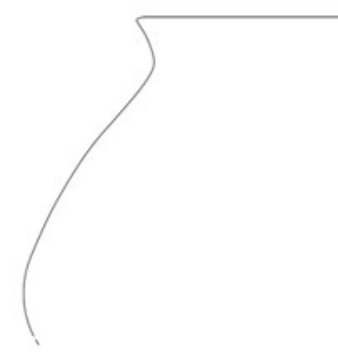

9
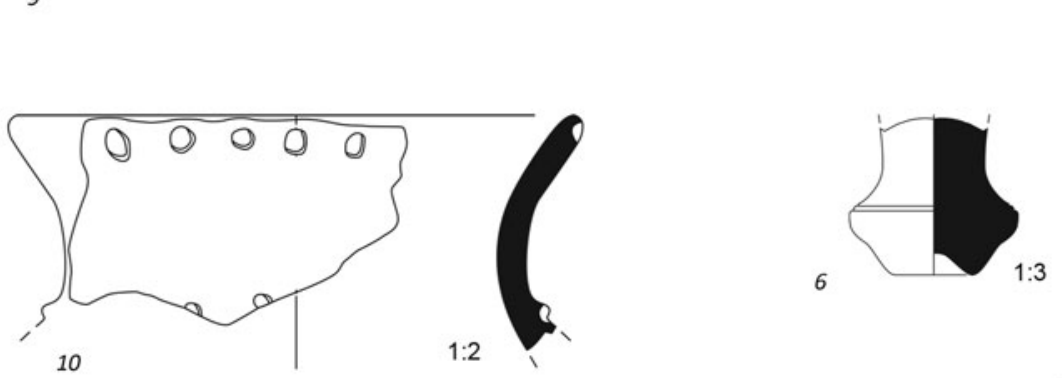

4 ro9 $\triangle 4 A=3 M$

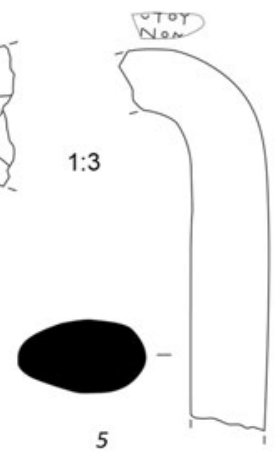

10

$1: 2$
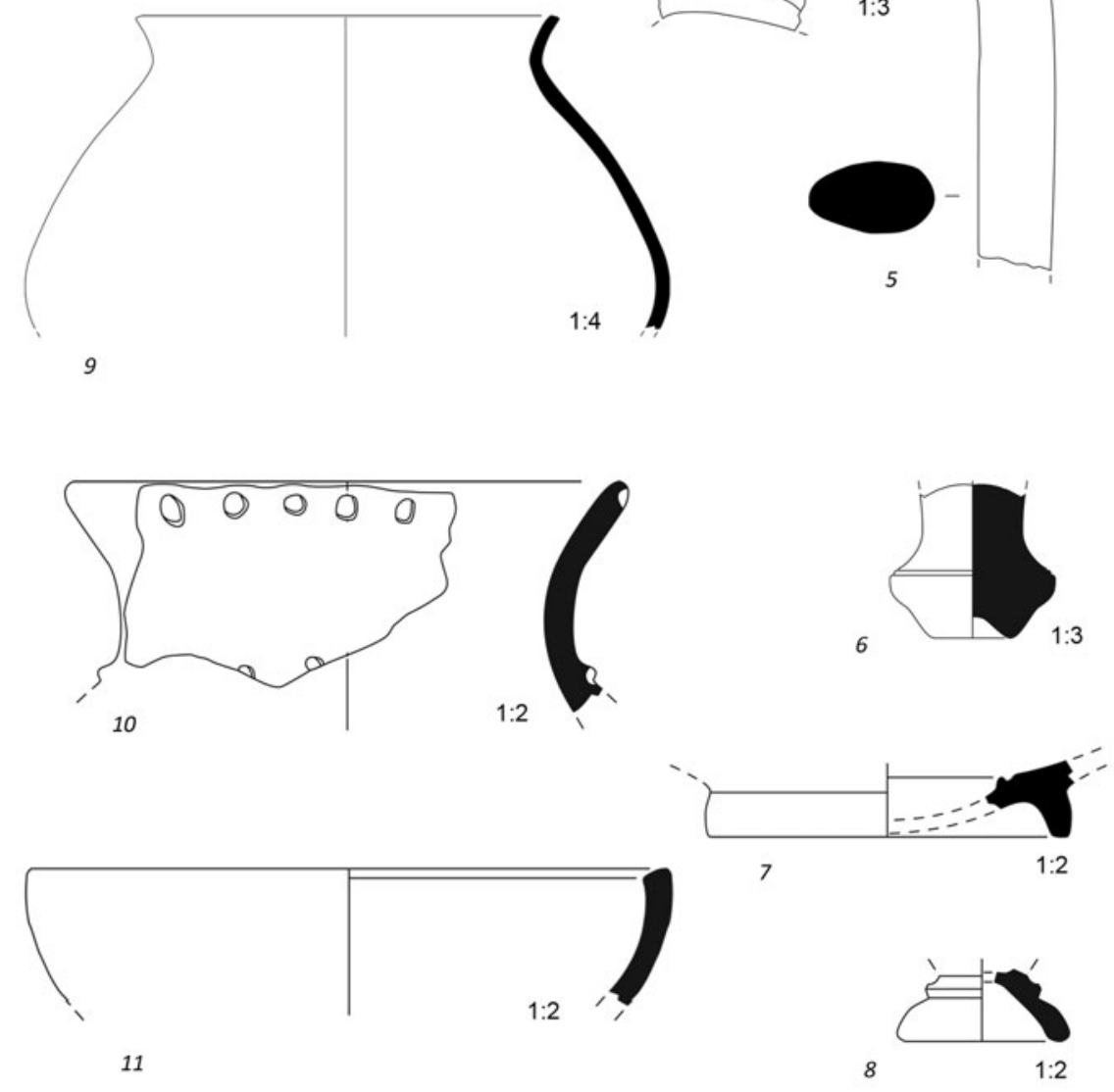

Figure 7. Pottery finds from house $H 1$ at Kelsheikh I.

to the considerably richer pottery assemblages of the coastal sites destroyed at the same time. In terms of wheel-turned pottery, only amphora fragments are abundant. The scarcity of other types of pottery (such as table and cooking ware) was compensated for by handmade bowls and pots, the percentages of which are noticeably higher than at the Greek farms on the coast (Stolba 2012: 340, tab. 1).

(C) Antiquity Publications Ltd, 2015 
A mushroom rim of a south-eastern Aegean amphora used as wall-building material (Figure 7, no. 1) provides a terminus post quem for construction in the second half of the fourth century BC (see Lawall et al. 2010: 371). However, a more accurate date (c. 325-300 BC) is suggested by the toe of a Chersonesean Type-IB amphora (cf. Monachov 1989: pl. XXII.27), which was used as building material in the foundations of the house. Most of the dateable pottery comes from the same period, with a limited supply after $300 \mathrm{BC}$. The latest reliably dateable finds are a black-glazed Attic fish plate from around 310-290 BC (Rotroff 1997: nos. 711-14) and fragments of Chersonesean amphorae stamped with the names of astynomoi (city magistrates) Alexander and Herodotos, who were active in 321-304 and 303-290 BC respectively (Stolba 2005a: 168-69; cf. Kac 2007: 326) (Figure 7, nos. 7 and $4 \& 5$ respectively).

\section{Site chronology}

The evidence from House 1 at Kelsheikh limits its lifetime to probably no more than 50 years of use. The earliest phase of the site (represented by storage pits) seems to coincide with the establishment of Chersonesos' distant chora, around 360 BC (Stolba 1991: 83, 2005a: 158-60, 2012: 318). Stratigraphy suggests that all pits, except perhaps 1 and 2, were filled shortly before the construction of $\mathrm{H} 1$. The stone building was constructed only decades later, simultaneously with buildings U6, U2, U13 and U14 at Panskoye I, Horizon A (Hannestad et al. 2002: 281; Stolba 2012: 319-20), which perhaps reflects a new wave of Chersonesean migration to north-western Crimea. Similar delayed emergence of stone dwellings can also be traced in the chorai of other Greek states in the northern Black Sea region such as Olbia and Theodosia (Kryžickij et al. 1989; Gavrilov 2004). The history of house $\mathrm{H} 1$, and the site, appears closely interwoven with that of the Chersonesean countryside. The end of H1 (and of Kelsheikh 1) is concurrent with the destruction and abandonment of the city's chora around $270 \mathrm{BC}$. The palaeoenvironmental data from Lake Saki suggest a climatic deterioration, which may have been responsible for the collapse of Greek economies in the area in the early third century BC. Attacks by nomads, which resulted in the final destruction of Greek rural territories, evidently only aggravated a general crisis (Stolba 2005b \& c, 2014).

\section{Conclusion}

Surface finds at other Kelsheikh 1 structures and the extensive survey evidence from similar settlements in the area suggest these were contemporary with H1. Dating and provenance of pottery from archaeological surveys and excavations, as well as numerous Chersonesean coins found by illicit metal detecting in the survey area link the inhabitants of Kelsheikh 1, and similar newly discovered settlements, to the Greek expansion. Even though the architecture of $\mathrm{H} 1$ is unusual in this region, the original layout, linear dimensions and building technique are most likely to have been inspired by Greek traditions, as suggested by parallels from the coastal sites of the Tarkhankut Peninsula. The evidence from the nearby settlement and necropolis of Panskoye I strongly suggests that the population of this settlement, and possibly that of many other sites in the distant chora of Chersonesos, was

(C) Antiquity Publications Ltd, 2015 
of mixed character; along with Greek farmers it is likely to have included Scythians and Taurians (cf. Stolba 2011; Stolba \& Rogov 2012). Whether indigenous (Taurian and/or Scythian) or mixed (Greek and non-Greek), it is likely that the inhabitants of Kelsheikh 1 worked in the tilled fields, serving the Chersonesean export of grain. However, this was not their only occupation. Unlike the inhabitants of the nearby chora, they lived outside the land division system, allowing their livestock to pasture in the untilled parts of the area. In spite of natural socio-political parallels with the Herakleian Mariandynoi and helots of Messenia and Laconia (Lotze 1959; Singor 1993; Luraghi \& Alcock 2003; Luraghi 2009), the social and juridical status of this population remains unknown. Moreover, archaeological exploration of the remaining parts of this territory will be necessary to assess adequately the whole range of the settlement's economic activities. However, even at such an early stage, it is apparent that, in combination with our surveys, the evidence from Kelsheikh 1 offers deeper and more varied insight into the complex organisation of the Chersonesean rural territory, the multi-ethnic composition of its population and the daily life of the Hellenistic Greek countryside on the northern shore of the Black Sea.

\section{Acknowledgements}

This work was carried out with financial support from the Danish Council for Independent Research (grant no. 09-069235). The satellite imagery grant was provided by the GeoEye Foundation.

\section{References}

ADAMESTEANU, D. 1974. La Basilicata antica: storia e monumenti. Cava dei Tirreni: Di Mauro.

Adam-Veleni, P., E. Poulaki \& K. Tzanavari. 2003. Ancient country houses on modern roads: central Macedonia. Athens: Archaeological Receipts Fund.

BinTliff, J. \& A. SNODGRASS. 1988. Off-site pottery distributions: a regional and interregional perspective. Current Anthropology 29: 506-13. http://dx.doi.org/10.1086/203668

BRONK RAMSEY, C. 2009. Bayesian analysis of radiocarbon dates. Radiocarbon 51: 337-60.

BUJSKICH, A.V. 2006. Do pytannja pro čas zasnuvannja Chersonesa Tavrijs'kogo. Archeologija (Kiev) 3: 35-44 (in Ukrainian).

CARTER, J.C. 2006a. Discovering the Greek countryside at Metaponto. Ann Arbor: University of Michigan.

- 2006b. Towards a comparative study of chorai west and east: Metapontion and Chersonesos, in P. Guldager Bilde \& V.F. Stolba (ed.) Surveying the Greek chora: the Black Sea region in a comparative perspective: 175-205. Aarhus: Aarhus University Press.

Carter, J.C., M. Crawford, P. Lehman, G. Nikolaenko \& J. Trelogan. 2000. The chora of Chersonesos in Crimea, Ukraine. American Journal of Archaeology 104: 707-41. http://dx.doi.org/10.2307/507154
CARTLedge, P. 1998. The economy (economies) of ancient Greece. Dialogos 5: 4-24.

ÇELEBI, E. 2008. Kniga putěsestvija. Krym i sopredel'nye oblasti. Izvlečenija iz sočinenija tureckogo putešestvennika XVII veka. Simferopol: Dolja (in Russian).

Cherry, J.F. 2003. Archaeology beyond the site: regional survey and its future, in J.K. Papadopoulos \& R.M. Leventhal (ed.) Theory and practice in Mediterranean archaeology: Old World and New World perspectives: 137-59. Los Angeles: University of California Press.

Chtcheglov, A. 1992. Polis et chora. Cité et territoire dans le Pont-Euxin. Paris: Belles Lettres.

DaševsKaja, O.D. \& A.S. GolenCov. 1999. Zapadno-Donuzlavskoe gorodišče v Krymu, in A.I. Meljukova, M.G. Moškova \& V.A. Bašilov (ed.) Evrazijskie drevnosti. 100 let B.N. Grakovu: 161-77. Moskva (in Russian).

ETHELBERG, L. 1966. Seasonal dwellings of farmers in north-western Luristan. Folk 8-9: 373-401.

FEILBERG, C.G. 1944. La tente noire: contribution ethnographique à l'histoire culturelle des nomades. Copenhague: Nationalmuseet.

FINLEY, M.I. 1987-1989. The city. Opus 6-8: 303-15.

FOXHALL, L. 2004. Small rural farmstead sites in ancient Greece: a material-cultural analysis, in F. Kolb (ed.) Chora und Polis: 249-70. München: Oldenbourg. http://dx.doi.org/10.1524/9783486594577.249 


\section{Unveiling the hinterland}

Galaty, M.L., S. MuçAJ, S.R. STOCKer, M.E. Timpson \& J.L. DAVIS. 2004. Excavation of a Hellenistic farmhouse in the vicinity of Apollonia, in P. Cabanes \& J.-L. Lamboley (ed.) L'Illyrie méridionalle et l'Épire dans l'Antiquité-IV: 299-305. Paris: De Boccard.

GaVrilov, A.V. 2004. Antičnaja okruga Feodosii. 409 Simferopol: Azbuka (in Russian).

Guldager Bilde, P., P. AtTema, S.B. Lancov, T.N. SMEKalova, V.F. STOlba, T. DE HaAs, S. HANDberg \& K. Winther Jacobsen. 2007. Džarylgačskij issledovatel'skij proekt: rezul'taty sezona 2007 g., in V. Ju. Zuev (ed.) Bosporskij fenomen: problemy chronologii i datirovki pamjat nikov. Part 2: 107-18. Sankt-Peterburg: Gosudarstvennyj Ermitažh (in Russian).

Guldager Bilde, P., P. ATtema \& K. WinTHER JACOBSEN (ed.). 2012. The Džarylgač Survey Project. Aarhus: Aarhus University Press.

Hannestad, L., V.F. STOlba \& A.N. ŠčEglov (ed.). 2002. Panskoye I. Vol. 1. The monumental building U6. Aarhus: Aarhus University Press.

Hansen, M.H. 2006. The shotgun method: the demography of the ancient Greek city-state culture. Columbia: University of Missouri Press.

Jones, J.E., L.H. SACKETT \& A.J. GRAhaM. 1962. The Dema House in Attica. The Annual of the British School at Athens 57: 75-114. http://dx.doi.org/10.1017/S0068245400013654

Jones, J.E., A.J. Graham \& L.H. SacketT. 1973. An Attic country house below the Cave of Pan at Vari. The Annual of the British School at Athens 68: 355-443. http://dx.doi.org/10.1017/S0068245400004524

KAC, V.I. 2007. Grečeskie klejma epochi klassiki i ellinizma. Simferopol-Kerch: Krymskoe Otd. Inst. Vostokovedenija im. A.E. Krymskogo NAN Ukrainy (in Russian).

Karamitrou-Mentesidi, G. 2009. Apo ten ereena sto frayma ilariona (Aliakmon): e anaskafe sto Meya Ae Yiorye kai Ayio Konstantino Themetras Yrevenon. Archaiologiko ergo stin Ano Makedonia 1: 108-31 (in Greek).

Keller, D.R. \& M.B. Walles. 1988. The Canadian Karystia Project: two Classical farmsteads. Échos $d u$ Mond Classique/Classical Views 32(7): 151-57.

KolEsNiKOV, A.B. 1984. Antičnye sel'skie usad'by u Evpatorijskogo majaka. Vestnik Moskovskogo Universiteta. Istorija 4: 76-86 (in Russian).

KOVALENKO, S.A. 1991. Antičnoe sel'skochozjastvennoe poselenie vozle sela Pesčanka, in Ju.L. Ščapova \& I.A. Jacenko (ed.) Pamjatniki železnogo veka v okrestnostjach Evpatorii: 6-36. Moskva: Izd-vo MGU (in Russian).

(C) Antiquity Publications Ltd, 2015
KRYŽICKIJ, S.D., S.B. BUJSKICH, A.V. BURAKOV \& V.M. OtrešKo. 1989. Sel'skaja okruga Ol'vii. Kiev: Naukova dumka (in Russian).

Lanza Catti, F., K. Swift \& J.C. Carter. 2014. The chora of Metaponto 5: a Greek farmhouse at Ponte Fabrizio. Austin: University of Texas Press.

LATYSHEV, B. 1916. Inscriptiones antiquae orae septentrionalis Ponti Euxini. Vol. I. St Petersburg.

LaWall, M.L., N.A. Lejpunskaja, P.D. Diatroptov \& T.L. SAMOJLOVA. 2010. Transport amphoras, in N.A. Lejpunskaja, P. Guldager Bilde, J.M. Højte, V.V. Krapivina \& S.D. Kryžickij (ed.) The Lower City of Olbia (Sector NGS) in the $\sigma^{\text {th }}$ century BC to the $4^{\text {th }}$ century AD: 355-405. Aarhus: Aarhus University Press.

LisetskiI, F.N., V.F. STOLBA, E.I. ERGINA, M.E. Rodionova \& E.A. TeReKHIN. 2013. Post-agrogenic evolution of soils in ancient Greek land use areas in the Herakleian Peninsula, south-west Crimea. The Holocene 23: 504-14. http://dx.doi.org/10.1177/0959683612463098

LoHmann, H. 1993a. Atene: Forschungen zu Siedlungsund Wirtschaftsstruktur des klassischen Attika. Köln: Böhlau.

- 1993b. Ein Turmgehoft klassischer Zeit in Thimari (Attika). Athenische Mitteilungen 108: 101-49.

LOTZE, D. 1959. Metaxy Eleutheron kai Doulon: Studien zur Rechtsstellung unfreier Landbevölkerungen in Griechenland bis zum 4. Jahrhundert v. Chr. Berlin: Akademie.

LURAGHI, N. 2009. The helots: comparative approaches, ancient and modern, in S. Hodkinson (ed.) Sparta: comparative approaches: 261-304. Swansea: Classical Press of Wales.

Luraghi, N. \& S.E. Alcock (ed.). 2003. Helots and their masters in Laconia and Messenia: histories, ideologies, structures. Cambridge (MA): Center for Hellenic Studies.

MASLENNIKOV, A.A. 1998. Ellinskaja chora na kraju ojkumeny. Moskva: Indrik (in Russian).

Mayнoff, K. (ed.). 1906. C. Plini Secundi Naturalis historia: libri XXXVII. 1, Libri I-VI. Leipzig: Teubner.

Monachov, S.J. 1989. Amfory Chersonesa Tavričeskogo $I V-I I v v$. do n.e. Saratov: Saratovskij gosudarstvennyj universitet (in Russian).

Müller, C. 1883. Claudii Ptolemaei geographia. E codicibus recognovit. Vol. 1.1. Paris: Didot.

NikolaEnKo, G.M. 2006. The chora of Tauric Chersonesos and the cadastre of the $4^{\text {th }}-2^{\text {nd }}$ century BC, in P. Guldager Bilde \& V.F. Stolba (ed.) Surveying the Greek chora: the Black Sea region in a comparative perspective: 151-74. Aarhus: Aarhus University Press. 
Osborne, R. 1992. 'Is it a farm?' The definition of agricultural sites and settlements in ancient Greece, in B. Wells (ed.) Agriculture in ancient Greece: 21-25. Stockholm: Swedish Institute at Athens.

Pentinnen, A. 2001. Berbati between Argos and Corinth: the excavations at Pyrgouthi in 1995 and 1997 from the Early Iron Age to the Early Roman period. Stockholm: Swedish Institute at Athens.

Pettegrew, D.K. 2001. Chasing the classical farmstead: assessing the formation and signature of rural settlement in Greek landscape archaeology. Journal of Mediterranean Archaeology 14: 189-209.

POPOVA, E.A. \& S.A. KovAlENKO. 2005. Istoriko-archeologičeskie očerki grečeskoj $i$ pozdneskifskoj kul'tur v Severo-Zapadnom Krymu. Moskva: Izd-vo MGU (in Russian).

RADDE, G.I. 2005. Krymskie tatary, in M.A. Aradžioni \& A.G. Gercen (ed.) Krymskie tatary: 370-414. Simferopol: Dolja (in Russian).

Reimer, P.J., M.G.L. BAillie, E. Bard, A. Bayliss, J.W. Beck, P.G. Blackwell, C. Bronk Ramsey, C.E. BuCK, G.S. BurR, R.L. EdwardS, M. Friedrich, P.M. GRoOTES, T.P. GuILDERSON, I. Hajdas, T.J. Heaton, A.G. HogG, K.A. Hughen, K.F. Kaiser, B. Kromer, F.G. MCCORMAC, S.W. MANNING, R.W. REIMER, D.A. Richards, J.R. SOUTHON, S. TAlamo, C.S.M. TURneY, J. VAN DER PliCHT \& C.E. WeyhenMeyer. 2009. IntCal09 and Marine09 radiocarbon age calibration curves, 0-50,000 years cal BP. Radiocarbon 51: 1111-50.

RotrofF, S.I. 1997. Hellenistic pottery: Athenian and imported wheelmade table ware and related material (The Athenian Agora 29). Princeton (NJ): American School of Classical Studies at Athens.

SAPRYKIN, S.J. 1994. Ancient farms and land-plots on the khora of Khersonesos Taurike. Amsterdam: Gieben.

- 2003. The Chersonesean farmhouse on land-plot no. 49 on the Lighthouse Point, in P. Guldager Bilde, J.M. Højte \& V.F. Stolba (ed.) The cauldron of Ariantas. Studies presented to A.N. Screglov on the occasion of his $70^{\text {th }}$ birthday: 145-63. Aarhus: Aarhus University Press.

ŠčEgLOV, A.N. 1978. Severo-Zapadnyj Krym v antičnuju epochu. Leningrad: Nauka (in Russian).

- 1980. Utilisation de la photographie aérienne dans l'étude du cadastre de Chersonésos Taurique (IVe-IIe s. av. n.è.). Dialogues de Histoire Ancienne 6: 59-72. http://dx.doi.org/10.3406/dha.1980.1400

- 1987. Un établissement rural en Crimée: Panskoje I (fouilles de 1969-1985). Dialogues de Histoire Ancienne 13: 239-73. http://dx.doi.org/10.3406/dha.1987.1759

Silberman, A. 1995. Arrien. Périple du Pont-Euxin. Texte établi et traduit par A. Silberman. Paris: Belles Lettres.
SINGOR, H.W. 1993. Spartan land plots and helot rents, in H. Sancisi-Weerdenburg (ed.) De agricultura. In memoriam Pieter Willem de Neeve: 31-60. Amsterdam: Gieben.

SmeKalova, T.N. \& V.F. STOLBA. 2009. Monuments of the Bronze Age and Early Iron Age on the Tarkhankut Peninsula: preliminary report. Simferopol: Dolja.

SNEGIN, E.A., F.N. LiseTSKII \& O.Y. ARTEMCHUK. 2014. Morphogenetic analysis of multitemporal populations of Helix albescens (Rossmaessler, 1839) from north-western Crimea on the basis of archaeological excavations at the settlement of Kelsheikh. Belgorod State University Scientific Bulletin: Natural Sciences 10(27): 83-87 (in Russian).

SOLOV'Ev, S.L. 2003. Archeologičeskie pamjatniki sel'skoj okrugi i nekropolja Nimfeja. Sankt-Peterburg: Gosudarstvennyj Ermitažh (in Russian).

STOJANOV, R.V. 2007. Neskol'ko zamečanij o vremeni i pričinach osnovanija Chersonesa Tavričeskogo. Vestnik Drevnej Istorii 2: 125-44 (in Russian).

STOLBA, V.F. 1991. Dom IV v. do n.e. na poselenii Panskoe I: raskopki 1987 g. Kratkie Soobščenija Instituta Archeologii 204: 78-84 (in Russian).

-2004. Karkinitis and the Bay of Karkinitis: towards an evaluation of the classical literary tradition. Ancient Civilizations from Scythia to Siberia 10: 47-66. http://dx.doi.org/10.1163/1570057041963976

- 2005a. Hellenistic Chersonesos: towards establishing a local chronology, in V.F. Stolba \& L. Hannestad (ed.) Chronologies of the Black Sea area in the period c. 400-100 BC: 153-77. Aarhus: Aarhus University Press.

- 2005b. Monetary crises in the Early Hellenistic poleis of Olbia, Chersonesos and Pantikapaion: a re-assessment, in C. Alfaro, C. Marcos \& P. Otero (ed.) XIII Congreso Internacional de Numismática (Madrid, 2003). Actas: 395-403. Madrid: Ministerio de Cultura.

-2005 c. The oath of Chersonesos and the Chersonesean economy in the Early Hellenistic period, in Z.G. Archibald, J.K. Davies \& V. Gabrielsen (ed.) Making, moving and managing. The new world of ancient economies, 323-31 BC: 298-321. Oxford: Oxbow.

- 2009. Beads, pendants and charms: the evil eye belief among the Greek and indigenous population of Taurica. Vestnik Drevnej Istorii 2: 109-28.

- 2011. Multicultural encounters in the Greek countryside: evidence from the Panskoye I necropolis, western Crimea, in E. Papuci-Wladyka, M. Vickers, J. Bodzek \& D. Braund (ed.) Pontika 2008. Recent research on the northern and eastern Black Sea in ancient times (British Archaeological Reports international series 2240): 329-40. Oxford: Archaeopress. 


\section{Unveiling the hinterland}

- 2012. La vie rurale en Crimée antique: Panskoye et ses environs. Études de Lettres 1-2: 311-64.

- 2014. Greek countryside in ancient Crimea: Chersonesean chora in the Late Classical to Early Hellenistic period. Aarhus: Faculty of Arts, Aarhus University.

Stolba, V.F. \& E. Rogov. 2012. Panskoye I. Vol. 2. The necropolis. Aarhus: Aarhus University Press.

Stolba, V.F., T.N. SmeKalova, I.N. Khrapunov, J. ANDRESEN \& S.A. MULD. 2011. Investigations in western Crimea, in D.N. Kozak (ed.) Archaeological researches in Ukraine, 2010: 316-17. Kiev-Poltava: Instiytut archeolohiji NANU.

StOlba, V.F., J. ANDRESEN, F.N. LisETSKII \& I.N. KHRAPUNOV. 2013. Investigations at the settlement of Kelsheikh 1, north-western Crimea, in D.N. Kozak (ed.) Archaeological researches in Ukraine, 2012: 107-109. Kiev-Poltava: Instiytut archeolohiji NANU.

STRŽELECKIJ, S.F. 1961. Klery Chersonesa Tavričeskogo. K istorii drevnego zemledelija v Krymu (Chersonesskij Sbornik 6). Simferopol: Krymizdat (in Russian).
TunkinA, I.V. 2003. The formation of a Russian science of classical antiquities of southern Russia in the $18^{\text {th }}$ and early $19^{\text {th }}$ century, in P. Guldager Bilde, J.M. Højte \& V.F. Stolba (ed.) The cauldron of Ariantas. Studies presented to A.N. Sčeglov on the occasion of his $70^{\text {th }}$ birthday: 303-64. Aarhus: Aarhus University Press.

Vinogradov, Ju.G. \& M.I. ZolotareV. 1990. La Chersonèse de la fin de l'archaïsme, in O. Lordkipanidze \& P. Lévêque (ed.) Le Pont-Euxin vu par les Grecs. Sources écrites et archéologie: 85-119. Paris: Belles Lettres.

- 1999. Chersones iznačal'nyj, in A.V. Podosinov (ed.) Severnoe Pričernomor'e v antičnosti: Voprosy istočnikovedenija: 91-129. Moskva: Nauka (in Russian).

ZIN'KO, V.N. 2003. Chora Bosporskogo goroda Nimfeja (Bosporskie Issledovanija 4). Simferopol-Kerch: Demetra Foundation (in Russian).

ZuBAR', V.M. 2007. Chora Chersonesa Tavričeskogo na Geraklejskom poluostrove: Istroija raskopok i nekotorye itogi izučenija. Kiev: Stilos (in Russian).

TALBERT, R.J.A. (ed.). 2000. Barrington atlas of the Greek and Roman world. Princeton (NJ): Princeton University Press.

Received: 9 October 2013; Accepted: 18 February 2014; Revised: 2 April 2014 